\title{
Prediction of Ship Main Engine Failures by Artificial Neural Networks
}

\author{
Burak GÖKSU' ${ }^{1}$ Kadir Emrah ERGINER ${ }^{1}$
}

\author{
${ }^{1}$ Dokuz Eylül University, Maritime Faculty, Turkey \\ burak.goksu@deu.edu.tr; ORCID ID: https://orcid.org/0000-0002-6152-0208 \\ emraherginer@gmail.com; ORCID ID: https://orcid.org/0000-0002-2227-3486 \\ Corresponding Author: Kadir Emrah ERGINER
}

\begin{abstract}
Maintenance practices are considered as the means of providing safety and security to environment and quality service, and despite increasing the costs for companies with certain increments, they contribute to their reputation and reliability. Maintenance planning of ships consists of setting priorities and planning the efficient use of the sources. One of the main objectives of this study is to bring up more profits from commercial activities by optimizing the availability of vessels. Operational capacity is ensured by adopting a systematic and proper maintenance policy that increases effectiveness and efficiency by reducing downtime. To reach at such a target, recent failure data is analyzed and through this analysis certain procedures are developed for spare parts availability and these procedures are utilized in maintenance applications.

This study aims to provide an additional feature for predictive maintenance software for the analysis of the upcoming conditions of the main engine systems. In this study, the history of failure in the critical nine main engine related subsystems have been analyzed by artificial neural network method, which is consistent with condition-based maintenance applications and subsequently helps to bring out the potential breakdowns in the recorded history of failure.
\end{abstract}

\section{Keywords}

Neural Networks, Planned maintenance, Ship engine failures.

\section{Introduction}

The main purpose of shipping companies in the maritime sector is to ensure that the effects on people, goods and the environment are at minimum level during the operation of the ships. To achieve this goal, IMO (International Maritime Organization) regulates the rules that can be globally accepted and applied. One of these is the ISM (International Safety Management) Code requires the administration board of shipping companies to ensure that ship operations are safe and secure, that all identified risks are assessed and that 
appropriate safety precautions are taken, land and ship personnel are prepared for safety and environmental emergency and safety management skills are constantly improved [1].

In order to fulfill the requirements of the ISM Code applied to the ships, a Safety Management System (SMS) should be established and the authorities and responsibilities should be determined for the system to work. When the system is put into use, reports should be kept as a result of periodic inspections and should be carried out under the ISM Code regulations to remove any non-conformities that may adversely affect the operation of the system. These non-conformities may be related to administrative or technical matters concerning ship activities. Maintenance of the machinery systems can be done by the personnel working on board, the shipyard or the maintenance team provided from the outsourced services [2]. Machinery maintenance tasks are organized as a result of recommendations of manufacturers, international conventions or experiences gained by companies. The fact that maintenance is applied to ship machinery and equipment periodically, does not mean that there will not be any breakdown between the two-neighbor maintenance. Such points as the quality of the used spare parts, human sourced neglect, oil/ fuel quality, weather conditions, route of the vessel, the experience of the previous maintenance personnel may cause any breakdown [3]. In Section 10 of the ISM Code, whilst shipping companies are held responsible for maintenance, how to do so is not limited to certain rules. On the contrary, it is imperative to adopt maintenance policies aimed at minimizing the damage to ships, seafarers, property and the environment.

Conventional fault prediction tools can be seen as a simple diagnostic method to identify the components or the whole system. This traditional technique, however, becomes inadequate when the components get complicated or when the system enlarges excessively, as it can clearly be seen with electric ships. For these complex systems, software tools may offer a solution [4]. For instance, from the manufacturing to the transportation sector, the companies that continue their maintenance and repair operations in an active-reactive manner have changed to complex activities in this regard [5]. Real-time data collection, classification, mapping and recording processes can be fully automated with modern computer technologies at low cost [6].

Considering these described aspects, this study primarily involves the definition of the equipment which will fail because of the unidentified reasons between the twoconsecutive maintenance. This prediction would be advantageous in optimizing not only the planning of maintenance applications but also the upcoming navigations. In the remainder of the study, the history of maintenance systems and maintenance strategies will be discussed to find out the tendency, which will help to grasp the gap in the literature. Then the methodology and the history of the failure data regarding the case study will be introduced. Finally, the results will be discussed.

\section{Background of Maintenance Systems}

All corrective and preventive activities carried out in the name of thorough operation of machinery and equipment are the requirements of production and service facilities, which is called maintenance. The function of maintenance is to restore the machine to its former efficiency due over time, to extend its useful lifetime, or to achieve the expected performance from a totally inoperable state [7], [8]. From a general point of view, the goals of maintenance are high availability, achieving 
the required quality level, applying safety precautions, realizing the production targets, optimizing energy and raw material usage [9], [10]. Figure 1 summarizes the factors that affect maintenance objectives and why maintenance is needed.

Changes in the maintenance techniques are seen in parallel with the growth in the number of the physical entities and the increasing complexity of them. To be able to distinguish between these changes in maintenance activities, the following points should be taken into account [12]:

- The overall expectations from maintenance,

- Comments on repair and maintenance

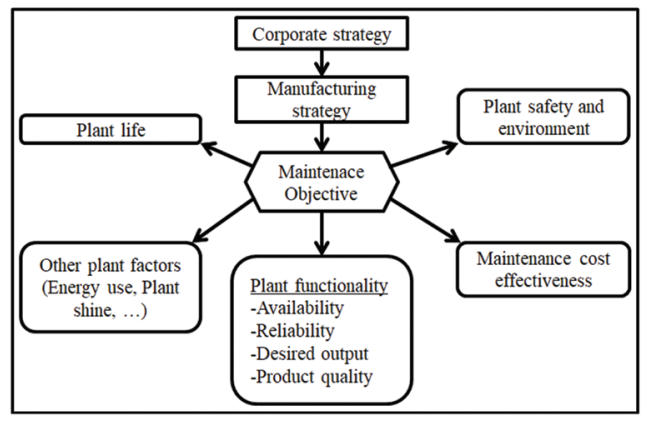

Figure 1: Maintenance Objective [11] of the equipment, and,

- Overviewing the changes in the applied maintenance techniques.

Table 1 shows the changes in the expectations, while Table 2 includes the evolution of the methods used to meet these expectations. The first generation covers the time until the Second World War. Following the widespread use of machines throughout the Second World War, expectations paved the way for the second generation. As of the mid-1970's, the acceleration of industrialization has led to the existence of the third generation [12].

Maintenance management consists of processes that include Planning and Implementation sections. In the planning section the correct definition of the strategy requires consideration of working plan and maintenance goals. The success of the maintenance depends on the program, control and inspection processes in the planning session. In the implementation section, it is aimed to achieve more efficient and more economical results than planned tasks [13]. Using a maintenance system with poor maintenance planning or disruptions because maintenance

Table 1: Changes in the Maintenance Expectations [12]

\begin{tabular}{|l|l|l|}
\hline \multicolumn{1}{|c|}{ First generation } & \multicolumn{1}{|c|}{ Second generation } & \multicolumn{1}{c|}{ Third generation } \\
\hline - Repair when corrupted & $\begin{array}{l}\text { - High plant life } \\
\text { - Longer equipment life } \\
\text { - Lower cost }\end{array}$ & $\begin{array}{l}\text { - High plant life and reliability } \\
\text { - Higher safety } \\
\text { - Better quality product } \\
\text { - No damage to the environment } \\
\text { - Longer equipment life } \\
\text { - More effectiveness in costs }\end{array}$ \\
\hline
\end{tabular}

Table 2: Changes in the Maintenance Techniques [12]

\begin{tabular}{|l|l|l|}
\hline \multicolumn{1}{|c|}{ First generation } & \multicolumn{1}{|c|}{ Second generation } & \multicolumn{1}{c|}{ Third generation } \\
\hline - Repair when corrupted & $\begin{array}{l}\text { - Planned maintenance } \\
\text { - Maintenance planning and } \\
\text { control systems } \\
\text { - Large, slow computers }\end{array}$ & $\begin{array}{l}\text { - Condition monitoring } \\
\text { - Reliability and maintenance } \\
\text { oriented design } \\
\text { - Risk analysis } \\
\text { - Small, fast computers } \\
\text { - Failure modes and effects } \\
\text { analysis } \\
\end{array}$ \\
& & $\begin{array}{l}\text { Expert systems } \\
\text { - Multiple skills and team work }\end{array}$ \\
\hline
\end{tabular}


and repair are critical to the ship; have effects on safety, security, efficiency and environmental considerations. Planning maintenance on ships requires a great effort about complicating time and personnel confinement, safety and security factors, international maritime rules and regulations, environmental risks, emergencies and disasters. Due to the complexity of ship systems, a comprehensive and planned system is needed. For this reason, it is of utmost importance to select the most appropriate maintenance system, implement the most effective strategy, and ensure reliable and efficient ship operations [14]. When establishing a safe working environment, it should be ensured that, in addition to risk assessment, maintenance of machinery and equipment should not lead to any dangerous situation [15]. The fact that ships are used in maritime transport is an important part of the supply chain cannot be denied. Due to the failure of any ship in the transportation system, expenditures will increase on both defective and rest side. The availability of ships depends on how the preventive maintenance system is effective [16].

In the maritime industry, maintenance activities are divided into such three categories, as corrective, preventive and predictive maintenance. The operating costs have been high on the vessels with insufficient maintenance activities; the availability of ship has decreased; and the inspections have increased. As a result of this, the staff on ships have suffered heavy working conditions [17]. Technical status of electrical and mechanical equipment on ships are measured as per such values as power, performance, malfunction and degradation. Due to the variety of the equipment, the relationship between the main structure and the components has had a complex structure. Technical difficulties arise with the addition of technology to the existing structure. The use of scientific information and comprehensive analysis methods seem to be appropriate for this situation [18]. When the ship machinery systems are examined, as a result of regular checks and inspections, it is observed that the condition-based maintenance has become increasingly widespread. The most considerable matters related to the protection of machinery and auxiliary systems are; petroleum (additives), refrigerants, gases, electrical/electronic equipment, gaskets and insulation materials. Improvements in maintenance procedures should be primarily motivated by cost efficiency, increased operational reliability and safety aspects, but should also contribute positively to the environment [19]. The planned maintenance system to be composed covers all belongings of the vessels and keeps a record of their documentation. Records must be on [20]:

- Maintenance log for equipment,

- The time interval for planned maintenance,

- Guiding instructions for staff who works on maintenance,

- The main sources of maintenance.

With the support of currenttechnological infrastructure, different techniques are used to measure and monitor the condition of ship machinery systems. In order to ensure the sustainability of these systems, it is tried to organize an optimum maintenance strategy by examining the instantaneous indicator values and failure records. On this context, Isa et al. [21] (2013), tried to predict the wear conditions of the ship machinery systems by taking samples from the oil circulating in the main engine, generator and gearboxes. It was determined whether these components need maintenance with the analysis of such physical aspects as flash point, viscosity measurement, ferrography analysis and energy dispersive Xray analysis (EDX).

Machinery Risk Analysis (MRA) method 
was developed by Dikis et al. [22] (2015) with a methodology involves the generation of a Markov Chain model integrated with the advantages of Bayesian Belief Networks (BBNs). The raw sensor data was firstly classified according to the subsystems and components determined by the experts. In the second stage, the risk and reliability analysis were applied with the probabilistic and mathematical modelling by BBN. The final stage has the decision-making process which involves short and long term predictions and decision features. Finally, the filtered/processed data was transformed into component reliability inputs such as failure rates, Mean Time Between Failures (MTBF) and probability of failure. In this way, failure occurrence, probable time of failure and components, subsystems and systems to be affected are predicted.

Gkerekos et al. [23] (2016), tried to develop a sustainable and profitable maintenance strategy using the ship machinery vibration data. The vibration values produced in the case of a healthy and faulty operation were classified and it was decided what condition the newly acquired data belonged to. In this way, flexible maintenance application is provided by early detection and elimination of emerging machinery failures.

Emovon et al. [24] (2018), wanted to achieve optimum ship main engine system reliability and safety by a sound maintenance management system. To achieve this, risk assessment, maintenance interval determination and maintenance strategy optimization of the system were evaluated by a multi-criteria decision making (MCDM) method.

Lazakis et al. [25] (2018), aimed to provide a systematic approach to identify critical ship machinery systems/ components and analyzed their physical parameters though the combination of Fault Tree Analysis (FTA) and Failure Mode and Effects Analysis (FMEA). A dynamic time series was used as input in the artificial neural network to predict future values of physical parameters related to critical ship main engine systems/ components. The predicted upcoming exhaust gas temperatures of the main engine cylinders were used for validation of actual observations on board the ship.

Maritime companies benefit from Computerized Maintenance Management Systems (CMMS) which can be embedded in any software or compiled as a standalone version. These systems have the functions of increasing productivity, reducing costs and ensuring that assets are effectively used in manufacturing or service processes. There are countless software companies operating in the field of CMMS due to the diversity of anticipations in the working areas of industrial companies [26]. The main functions of CMMS are expressed as [27]:

- Easy job order management,

- Planning,

- Scheduling,

- Control of income/expenditure,

- Spare parts management, and

- Key performance indicator control.

Although CMMS software are tools to help solve problems, they cannot succeed at maintenance management problems. The general purposes of these software are listed as; maintenance status monitoring, control of sources, control of suitability for the targets of the company, safety, security and the inclusion of quality policies in the maintenance processes [28]. The ability to handle large amounts of data quickly in CMMS is crucial to managing the assets of organizations. Reports on statistics, highlighting key performance notes and troubleshooting provide the possibility of predicting for staff working on maintenance management [29].

The aim of this study is to determine the approximate date of upcoming failures 
of main engine and related subsystems by analyzing the information in CMMS without human factor. Although noteworthy defects, as a result of reports, notes and inspections, are prominent, they are not impressive in the planning stage considered as maintenance. The Artificial Neural Networks method has been preferred as it has eliminated the human factor due to its self-learning ability.

\section{Material and Methodology}

The historical development of maintenance systems and the expectations from these systems in industry and maritime transport have been summarized in part 2. By using a machine learning algorithm, Artificial Neural Networks (ANN), this research aims to have CMMS get the ability to estimate the upcoming failure. ANN demonstrates not only engineering, science and mathematics, but also exemplary applications in that it is good at the solution of medicine, business, finance and literature [30]. The selected method can provide the necessary modelling to the user without the need for any preliminary information and assumptions between input and output variables. For this reason, ANN has been preferred as the methodology for this study.

ANN is the realization of the learning function, the most basic feature of the human brain, by computer systems. The learning process is carried out with the help of examples. The network is formed by

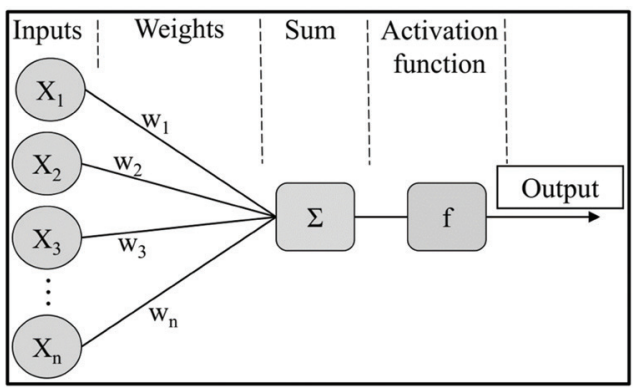

Figure 2: Mathematical Model of Single Layer Artificial Neurons [32]

Source: Reorganized by the authors interconnecting of process elements called artificial neurons as shown in Figure 2. Each link has a weight value and the information that the artificial neural network processes is hidden in these weight values and spread to the network [31].

Each layer of the network includes the input vector, the weight matrix, the summation, the transfer function and the output vector. The elements in the input vector are connected to the neurons by their weight values. Each neuron involves the output vector, summation and transfer functions. In the creation of a neural network, the following three features should be considered [30]:

- Number of inputs,

- Number of neurons in output layer,

- Output layer transfer function

It is advised that a cycle be performed as shown in Figure 3, when it is expected to be a successful artificial neural network. All the processes starting from the Phase 1 have been carried out respectively, if the desired performance has not been reached, the operations at each step must be reviewed. The result of such a cycle through which the system inputs and parameters are reviewed and revised is unlikely to fail [33].

The most substantial feature that

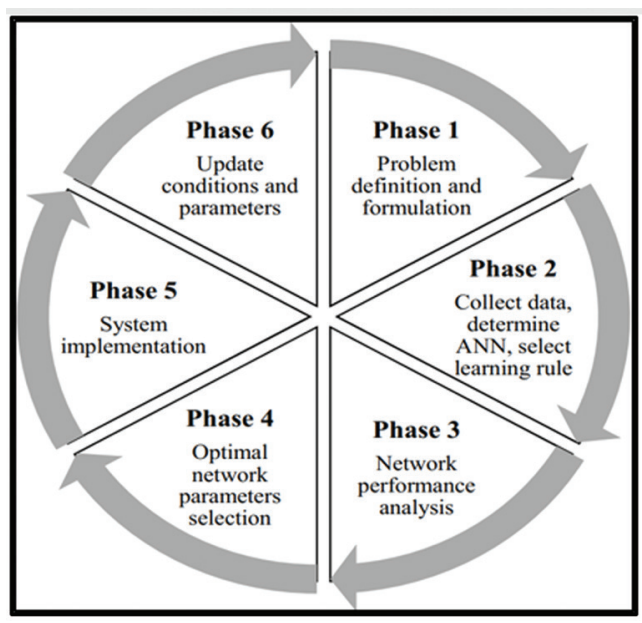

Figure 3: Cycle of an ANN Project

Source: Composed by the authors 
distinguishes ANN is its ability to adapt to the medium that it is in. There is no specific standard in determining the structure of the network to be created and in selecting the network parameters. Because numerical information is the only input of the ANN, the time spent to finish the training is uncertain and the behavior of the network cannot be thoroughly defined so the need for expert users is inevitable [34]. ANN has in general pattern association, data clustering, learning statistical parameters and function approximation applications [35]. The fact that a well-trained network gives high-accurate results in different fields is one of the reasons that encourages the use of ANN.

\section{Case Study}

This study aims to predict equipment failures which are related to main engine and its auxiliary systems used in ships. A 10-year failure history has been used in this predictive study. The history has been recorded in a planned maintenance software, which has a type approve by DNVGL for ISM code requirements. Maintenance record of the ship includes the components of the systems, the date of the failure and the maintenance process history. The components of the main engine and its subsystems belonging to the ship used here as the case ship have been used within the form of the output from the planned maintenance management software without any changes. Table 3 shows the above mentioned structure; there are 9 systems classified as main engine and its subsystems and 220 failures have been recorded in the last ten years. As a matter of confidentiality agreement, the information about the company and the ship, a container ship, is kept a confidential.

There are 47 components of the systems mentioned in Table 3. The names of the components, the system to which they belong, the component numbers, and the failure quantity of these components are shown in detail in Table 4.

The gathered failure data must be transformed into a matrix form in order to be transferred to the Artificial Neural Network tool used in the MATLAB $B$ software. In Table 5 the component failures are indicated by $0-1$ logic in Columns 1 to 47 which represents the components mentioned in Table 4 . The records taken like time series based on "days" about the issue of "failures" have a value of " 1 " when there is any failure, and " 0 " when there is no failure. The day when the failure occurred is indicated in the last column. Because

Table 3: Main Engine Related Systems and Failure Distributions

\begin{tabular}{|c|l|c|c|}
\hline System no & \multicolumn{1}{|c|}{ System Name } & Failure Quantity & Percentage (\%) \\
\hline 1 & Air Charge System & 8 & 21.6 \\
\hline 2 & Fuel System & 1 & 0.5 \\
\hline 3 & Hydraulic System & 19 & 8.6 \\
\hline 4 & Lubrication System & 72 & 32.7 \\
\hline 5 & Main Engine & 9 & 4.1 \\
\hline 6 & Cooling System & 24 & 10.9 \\
\hline 7 & Exhaust System & 23 & 10.5 \\
\hline 8 & Maneuver System & 16 & 7.3 \\
\hline 9 & Starting System & 220 & 100 \\
\hline
\end{tabular}

Source: Gathered by the authors 
Table 4: Detailed Failure Distribution of the Components

\begin{tabular}{|c|c|c|c|c|c|c|c|}
\hline $\begin{array}{l}\text { System } \\
\text { name }\end{array}$ & $\begin{array}{c}\text { Comp. } \\
\text { no }\end{array}$ & Comp. name & $\begin{array}{l}\text { Failure } \\
\text { number }\end{array}$ & $\begin{array}{c}\text { System } \\
\text { name }\end{array}$ & $\begin{array}{l}\text { Comp. } \\
\text { no }\end{array}$ & Comp. name & $\begin{array}{l}\text { Failure } \\
\text { number }\end{array}$ \\
\hline \multirow{2}{*}{$\begin{array}{l}\text { Air Charge } \\
\text { System }\end{array}$} & 105 & Auxiliary blower & 5 & \multirow{12}{*}{$\begin{array}{l}\text { Main } \\
\text { Engine }\end{array}$} & 505 & Oil mist & 11 \\
\hline & 110 & Turbocharger & 3 & & 510 & Piston ring & 10 \\
\hline \multirow{12}{*}{$\begin{array}{l}\text { Fuel } \\
\text { System }\end{array}$} & 205 & System failure & 5 & & 515 & Cylinder cover & 9 \\
\hline & 210 & $\begin{array}{l}\text { Fuel pump top } \\
\text { cover }\end{array}$ & 2 & & 520 & Governor & 5 \\
\hline & 215 & Viscometer & 4 & & 525 & $\begin{array}{l}\text { Main structural } \\
\text { parts }\end{array}$ & 12 \\
\hline & 220 & Water mist & 1 & & 530 & Main engine block & 6 \\
\hline & 225 & Fuel pump & 20 & & 535 & Crankcase & 2 \\
\hline & 230 & $\begin{array}{l}\text { Fuel pump suction } \\
\text { valve }\end{array}$ & 3 & & 540 & Liner & 2 \\
\hline & 235 & $\begin{array}{l}\text { Fuel pump function } \\
\text { valve }\end{array}$ & 3 & & 545 & $\begin{array}{l}\text { Connecting rod } \\
\text { bearing }\end{array}$ & 3 \\
\hline & 240 & Fuel injector & 5 & & 550 & Crank pin & 1 \\
\hline & 245 & Flowmeter & 2 & & 555 & Main engine sensors & 2 \\
\hline & 250 & $\begin{array}{l}\text { High pressure fuel } \\
\text { hose }\end{array}$ & 1 & & 560 & Piston & 9 \\
\hline & 255 & Fuel valves & 1 & \multirow{4}{*}{$\begin{array}{l}\text { Cooling } \\
\text { System }\end{array}$} & 605 & Cooling oil & 5 \\
\hline & 260 & $\begin{array}{l}\text { Fuel non-return } \\
\text { valves }\end{array}$ & 1 & & 610 & Cylinder cover & 2 \\
\hline $\begin{array}{l}\text { Hydraulic } \\
\text { System }\end{array}$ & 305 & Hydraulic System & 1 & & 615 & Cooling water & 1 \\
\hline \multirow{4}{*}{$\begin{array}{l}\text { Lubrication } \\
\text { System }\end{array}$} & 405 & Alfa lubricator & 5 & & 620 & Liner & 1 \\
\hline & 410 & Lubrication pump & 2 & \multirow{4}{*}{$\begin{array}{l}\text { Exhaust } \\
\text { System }\end{array}$} & 705 & Exhaust System & 4 \\
\hline & 415 & Cylinder lubricator & 7 & & 710 & $\begin{array}{l}\text { Exhaust valve } \\
\text { actuator }\end{array}$ & 7 \\
\hline & 420 & Lubrication & 5 & & 715 & $\begin{array}{l}\text { Exhaust non-return } \\
\text { valves }\end{array}$ & 1 \\
\hline \multirow{5}{*}{$\begin{array}{l}\text { Maneuver } \\
\text { System }\end{array}$} & 805 & Engine telegraph & 9 & & 720 & Exhaust valves & 12 \\
\hline & 810 & Control failure & 10 & \multirow{2}{*}{$\begin{array}{l}\text { Starting } \\
\text { System }\end{array}$} & 905 & Starting air & 6 \\
\hline & 815 & $\begin{array}{l}\text { Maneuver system } \\
\text { failure }\end{array}$ & 2 & & 910 & $\begin{array}{l}\text { Turning wheel } \\
\text { motor }\end{array}$ & 4 \\
\hline & 820 & System sensors & 2 & & 915 & $\begin{array}{l}\text { Auxiliary blower } \\
\text { motor }\end{array}$ & 2 \\
\hline & & & & & 920 & Starting system & 4 \\
\hline
\end{tabular}


the actual failure matrix size is $3630 \times 48$, a sample segment of the matrix is given short form in Table 5 .

For a better understanding of the above table; an example can be given as follows: the cell value of the component 110 on the 169 th day has " 1 ", because that day a fault occurred. On the 169 th day, " 0 " is written to the cells belonging to the other components where no failure occurred. Since the planned maintenance system of the ship does not contain any failure record for two or more components on the same day, such a case is not included in the matrix.

The input data is compiled when the data in Table 4 is converted to the form of Table 5. The first two phases of the cycle are fulfilled up to this point. For Phase 3 and 4 , the performance criteria of different networks should be compared, and the optimal results should be determined by heuristic approach. In Table 6, the key performance indicators are evaluated as
"Mean Square Error", "Regression" and "Time". These indicators are compared with each other by "the number of the hidden neurons" and "the percentage of the data partitioning" values. When deciding on the optimal parameters, the Regression (R) and Mean Squared Error (MSE) values of the network trained by the LevenbergMarquardt (LM) method are indicated in Table 6-8. The fact that the LM algorithm is intended for the ability of quick learning characteristic [30].

MSE is one of the performance parameters, the average squared difference between output and target values of the ANN. The lowest MSE values are preferred and " 0 " indicates zero error. Regression (R) measures the correlation between the output and the target, and it has a maximum value " 1 " meaning a close relationship, " 0 " is for random relationship [36]. The elapsed duration between the beginning of the training and the end of the simulation

Table 5: ANN Failure Matrix

\begin{tabular}{|c|c|c|c|c|c|c|c|}
\hline $\mathbf{1 0 5}$ & $\mathbf{1 1 0}$ & $\mathbf{2 0 5}$ & $\mathbf{2 1 0}$ & $\ldots$ & $\mathbf{9 1 5}$ & $\mathbf{9 2 0}$ & Days \\
\hline 0 & 0 & 0 & 0 & $\ldots$ & 0 & 0 & 1 \\
\hline 0 & 0 & 0 & 0 & $\ldots$ & 0 & 0 & 2 \\
\hline$\ldots$ & $\ldots$ & $\ldots$ & $\ldots$ & $\ldots$ & $\ldots$ & $\ldots$ & $\ldots$ \\
\hline 0 & 1 & 0 & 0 & $\ldots$ & 0 & 0 & 169 \\
\hline$\ldots$ & $\ldots$ & $\ldots$ & $\ldots$ & $\ldots$ & $\ldots$ & $\ldots$ & $\ldots$ \\
\hline 0 & 0 & 0 & 0 & $\ldots$ & 0 & 1 & 1189 \\
\hline$\ldots$ & $\ldots$ & $\ldots$ & $\ldots$ & $\ldots$ & $\ldots$ & $\ldots$ & $\ldots$ \\
\hline 0 & 0 & 0 & 0 & $\ldots$ & 0 & 0 & 3630 \\
\hline
\end{tabular}

Source: Compiled by the authors

Table 6: Performance Parameters and Data Partitioning (Training=60\%, Validation=20\%, Testing=20\%)

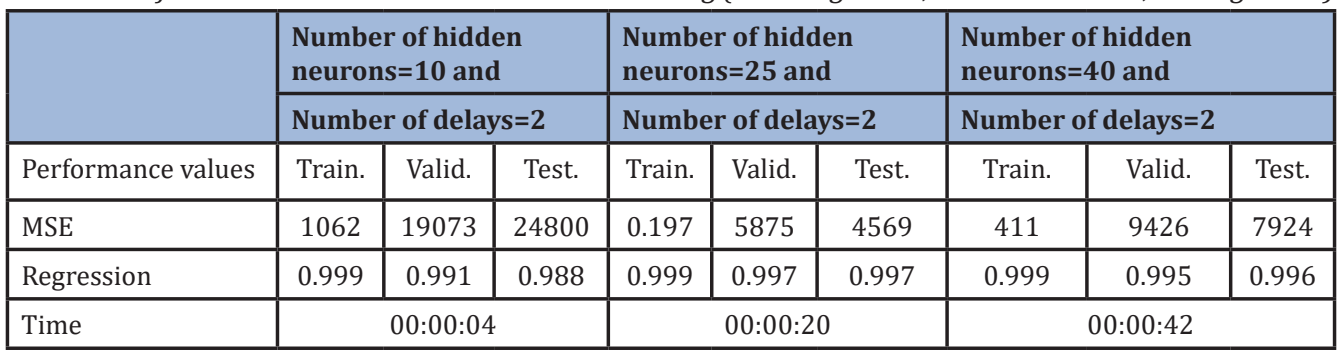

Source: Compiled by the authors 
Table 7: Performance Parameters and Data Partitioning (Training=70\%, Validation=15\%, Testing=15\%)

\begin{tabular}{|l|c|c|c|c|c|c|c|c|c|}
\hline & \multicolumn{3}{|l|}{$\begin{array}{l}\text { Number of hidden } \\
\text { neurons=10 and }\end{array}$} & \multicolumn{2}{l|}{$\begin{array}{l}\text { Number of hidden } \\
\text { neurons=25 and }\end{array}$} & \multicolumn{2}{l|}{$\begin{array}{l}\text { Number of hidden } \\
\text { neurons=40 and }\end{array}$} \\
\cline { 2 - 11 } & \multicolumn{2}{|l|}{ Number of delays=2 } & \multicolumn{2}{l|}{ Number of delays=2 } & \multicolumn{2}{l|}{ Number of delays=2 } \\
\hline Performance values & Train. & Valid. & Test. & Train. & Valid. & Test. & Train. & Valid. & Test. \\
\hline MSE & 52 & 2268 & 30688 & 9.59 & 2301 & 6372 & $7.4 \times 10^{-9}$ & 4291 & 2930 \\
\hline Regression & 0.999 & 0.999 & 0.986 & 0.999 & 0.999 & 0.997 & 0.999 & 0.998 & 0.998 \\
\hline Time & \multicolumn{3}{|c|}{$00: 00: 02$} & \multicolumn{3}{c|}{$00: 00: 22$} & & $00: 06: 50$ \\
\hline
\end{tabular}

Source: Compiled by the authors

Table 8: Performance Parameters and Data Partitioning (Training=80\%, Validation=10\%, Testing=10\%)

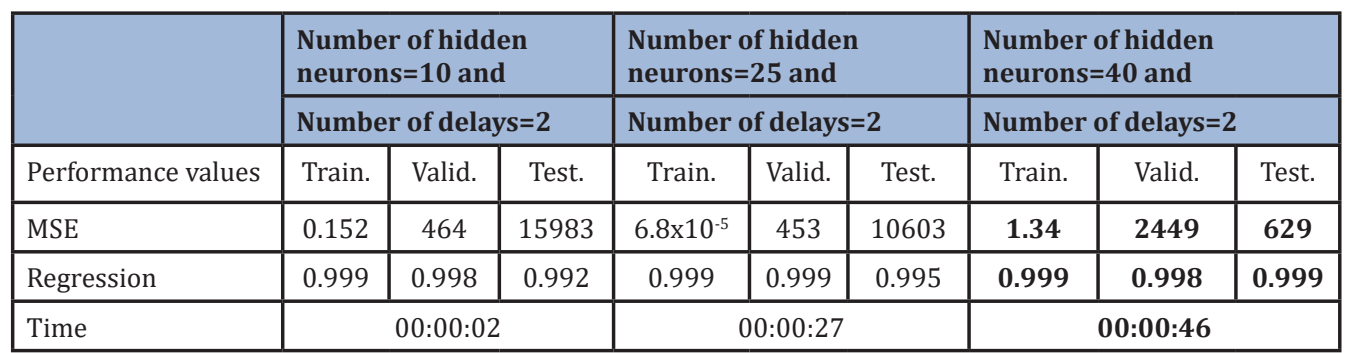

Source: Compiled by the authors

of the network is given as 'Time' variable. The comparison of MSE, $\mathrm{R}$ and Time values of the simulated networks are indicated in Table 6-8. The optimal parameters are determined as 40 hidden neurons and 2 delay time such as the partitioning of the data in Table 8 (Training $=80 \%$, Validation $=10 \%$, Testing $=10 \%$ ).

\section{Results and Findings}

The planned maintenance and failure history of a ship is the most significant point in the technical and administrative management of ship operations. Manufacturers use the failure data of their test devices and the products they sell while preparing the planned inspection and maintenance programs. However, the equipment on the ship's main engine and its connected systems is not only used in the ship but also in different places in the industry. Therefore, there is a problem in ability to identify the failures that trigger one another in different combinations of the systems. The test assemblies of these combinations should be carried out separately, to conduct more proper reliability analysis of the equipment, but no such system exists yet. This once again brings the importance of feedback mechanism. The ANN simulation results have been gathered in Table 9 .

The timeline in Figure 4 is formed to provide a more comprehensive view of the predicted values shown in Table 9. The bias value between the start of timeline and the end of the recorded date is emerged from ANN prediction method errors. This error is around $2 \%$ and is within the acceptable limits. However, the main issue to be concerned in this study is the sequence of failures and time difference between the malfunctions. According to the research, if personnel in charge of the maintenance has a procedure at hand like the one in Table 4 , a better practice will be carried out when any personnel starts the maintenance process from beginning of the timeline. 
Table 9: The Past and Predicted Failure Days of the Components

\begin{tabular}{|c|c|c|}
\hline $\begin{array}{l}\text { Comp. } \\
\text { no }\end{array}$ & The days of past the failures & $\begin{array}{l}\text { Predicted } \\
\text { failure }\end{array}$ \\
\hline 105 & $119,367,2916,2929,3378$ & 3638 \\
\hline 110 & $169,1465,1495$ & 3647 \\
\hline 205 & $1029,3431,3449,3568,3627$ & 3584 \\
\hline 210 & 3120,3319 & 3734 \\
\hline 215 & $1107,3071,3401,3608$ & 3610 \\
\hline 220 & 2967 & 3612 \\
\hline 225 & $\begin{array}{c}252,362,429,567,1072,1084,1085,2331,2618,2671,2690,2916,2957,3121 \\
3202,3221,3227,3232,3289,3563\end{array}$ & 3606 \\
\hline 230 & $2691,3328,3505$ & 3629 \\
\hline 235 & $3063,3109,3185$ & 3628 \\
\hline 240 & $187,668,1059,2380,2600$ & 3630 \\
\hline 245 & 2608,3195 & 3747 \\
\hline 250 & 2296 & 3653 \\
\hline 255 & 2598 & 3766 \\
\hline 260 & 1510 & 3640 \\
\hline 305 & 1579 & 3625 \\
\hline 405 & $2781,2910,2949,3044,3237$ & 3658 \\
\hline 410 & 3200,3226 & 3653 \\
\hline 415 & $1059,1243,1247,1249,1266,2359,3412$ & 3647 \\
\hline 420 & $2523,2602,2945,2975,3615$ & 3610 \\
\hline 505 & $2576,2583,2965,2979,2985,3107,3219,3246,3288,3345,3458$ & 3607 \\
\hline 510 & $1463,1809,1810,2578,2596,3014,3178,3192,3252,3344$ & 3634 \\
\hline 515 & $2267,2870,2887,3002,3124,3172,3198,3272,3395$ & 3669 \\
\hline 520 & $956,2677,2830,2907,3459$ & 3634 \\
\hline 525 & $929,1501,2445,2470,2472,2567,2694,2696,2812,2838,2840,3129$ & 3751 \\
\hline 530 & $967,974,1467,2120,2608,3076$ & 3692 \\
\hline 535 & 2711,3624 & 3582 \\
\hline 540 & 1688,3298 & 3612 \\
\hline 545 & $1579,2504,2505$ & 3629 \\
\hline 550 & 992 & 3592 \\
\hline 555 & 1,2478 & 3654 \\
\hline 560 & 2500, 2596, 2597, 2934, 2981, 2987, 3095, 3141, 3353 & 3663 \\
\hline 605 & $2969,3327,3343,3364,3629$ & 3672 \\
\hline 610 & 2627,2699 & 3565 \\
\hline 615 & 3579 & 3633 \\
\hline 620 & 3332 & 3652 \\
\hline 705 & $401,1259,3058,3400$ & 3595 \\
\hline
\end{tabular}


Table 9: The Past and Predicted Failure Days of the Components (cont.)

\begin{tabular}{|c|c|c|}
\hline $\begin{array}{c}\text { Comp. } \\
\text { no }\end{array}$ & The days of past the failures & $\begin{array}{l}\text { Predicted } \\
\text { failure }\end{array}$ \\
\hline 710 & $1316,1318,1370,1616,2811,3326,3610$ & 3637 \\
\hline 715 & 401 & 3647 \\
\hline 720 & $297,2296,2614,2781,2826,3164,3195,3216,3459,3475,3507,3551$ & 3620 \\
\hline 805 & $2237,2465,3169,3325,3361,3381,3451,3542,3564$ & 3694 \\
\hline 810 & $1257,1417,1579,1666,3010,3389,3509,3586,3609,3611$ & 3674 \\
\hline 815 & 3339,3627 & 3697 \\
\hline 820 & 3485,3592 & 3637 \\
\hline 905 & $98,2216,2465,2806,3453,3493$ & 3637 \\
\hline 910 & $2539,2788,3111,3364$ & 3657 \\
\hline 915 & 3459,3462 & 3644 \\
\hline 920 & $1189,1280,1416,3579$ & 3611 \\
\hline
\end{tabular}

Source: Compiled by the authors

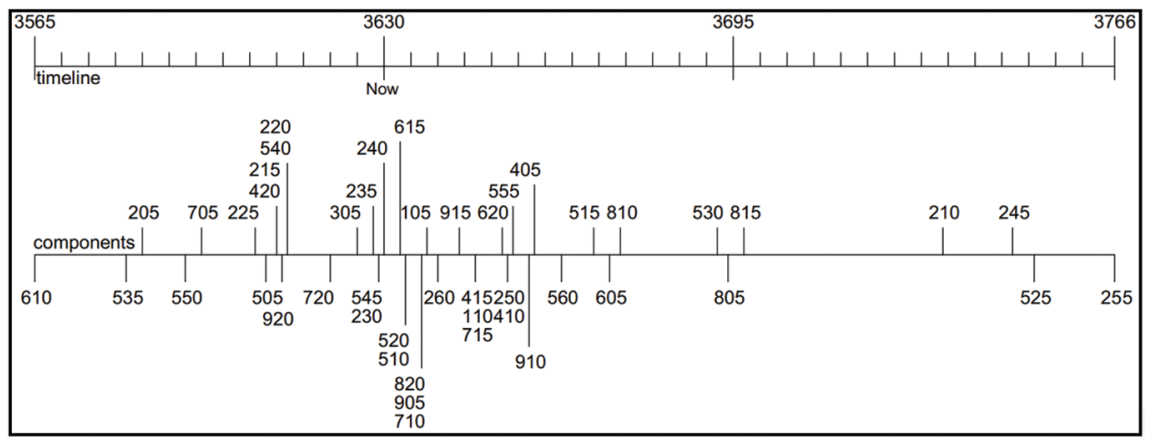

Figure 4: Failure Timeline of the Components

Source: Composed by the authors

\section{Conclusion and Discussions}

Repair and maintenance is a critical technical issue for ships. Although the equipment of ship is covered by planned maintenance, failures may occur due to their physical conditions. The overall condition of the ship is considered when planning maintenance and navigation. When a significant disruption and damaging situation of vessels with maintenance systems is investigated, it is understood that poor systems result in serious deterioration in safety, efficiency and environmental performance. Planned maintenance systems include extensive and periodic maintenance processes for systems and components. A PMS is organized by the shipping or the ship-owner company that is related to the requirements of the manufacturers, operators, management policy of the company and the ship classification societies. These systems have also strengths, weaknesses, conveniences and challenges. The PMS concept, when integrated into the safety management system, contributes significantly to strengthening the system performance and reliability.

When presumptions about future failures are known; maintenance, condition 
monitoring, necessary spare part orders can be reorganized. In addition, important information can be obtained to update daily, weekly, monthly or working hours based maintenance processes in the PMS. Similar studies on this subject offer different approaches to eliminate the worst cases. Dikis et al. [22] suggested a MRA methodology by reviewing the requests of existing CM systems. Dynamic (time-dependent) operating cases at the system, subsystem and component level were evaluated on the basis of reliability performance measurement, including various failure modes and failure case scenarios for the turbocharger and cargo pump. In order to test the requested methodology, the idea of installing an alarm and warning system in practice was proposed in the future study of Dikis et al. For a similar purpose, Isa et al. [21] conducted research to obtain highly reliable data and to plan better maintenance to prevent the destructive failures and expensive component changes of the main engines, generators and gearboxes of a commercial ship. Isa et al assert that particle size over $50 \mu \mathrm{m}$ indicates abnormal wear. Since the presence of these particles will cause the lubrication system to not operate efficiently and also the parts of the metallic components to be destroyed, urgent maintenance is recommended in the equipment if this situation is observed. Gkerekos et al. [23], tried to predict the occurrence of malfunction by detecting abnormal vibrations in the ship's main engine. The model conducted under two stage; data storage and anomaly detection. That case study demonstrated that Support Vector Machines (SVM) are the accurate models for machinery fault detection. The development of the anomaly detector/ classifier has been proposed in further study so that the discernment between different faults is possible. In this way, a Decision Support System provides guidance with regards to the selection of optimal maintenance actions. The main purpose of similar studies is that the causes of failures are not concerned, although the prediction of faulty component and the date of upcoming machinery failure is the most significant issue for the management of a sound maintenance plan. Comparing the two hybrid MCDM techniques, Emovon et al. [24] concluded that the "safety" factor has $50 \%$ of the total compared to all other criteria in the selection of maintenance techniques to be applied to ship machinery and equipment. It was concluded that the condition-based maintenance is the best-ranked maintenance strategy for the high pressure pump of the fuel oil system of the marine diesel engine. It was also emphasized that the transition from corrective maintenance and timebased preventive approaches to a safer and more reliable maintenance approach for any critical equipment belonging to a system. Lazakis et al. [25] claims that FMEA and FTA tools are complementary to each other and it is necessary to monitor the physical parameters as well as to determine the possible causes and effects of critical system failures. The use of ANN stems from the need to make time-series analysis of physical parameters. Based on past and current fault data, it is argued that diagnostic and performance measurement will contribute to the development of a sound maintenance strategy. It is also recommended to determine the critical deviations from the threshold value of the equipment and to identify those exceeding this threshold by the warning system in the future study.

The aim of this study is to predict which equipment will fail in the predicted future, using recorded failure data. The most striking feature of this predictive method is that the components in the system can provide different maintenance methods according to the failure paths. 
Artificial Neural Networks method, which is frequently used for predictive maintenance in the literature, has been adopted. The network was trained with the history of the failure data, and so the trained network was utilized as for the upcoming failures. The result of the analysis in Table 9 is for the end of 3630th day. Even after one day all these calculations must be repeated. The reason is that a new row of data has been added to the recorded failure data given in Table 5. To ensure precise predictions, the organized ANN model have to include the failure data obtained after 3630th day, and the model should be re-trained with new record. If the predictions wanted to be done continuously by artificially, the obtained future failure data for each day should be added in Table 5 and all the training and simulation stages must be iterated progressively. Otherwise, it is not conceivable to ask for a failure estimation from a static system.

In the operational phase, the diagnosis and upgrade processes are carried out based on the condition monitoring parameters integrated with the experience of the maintenance services. An optimized and predictable maintenance system is a guide for operators. If you believe that you employ experienced personnel, and support the staff with a system that works properly and makes accurate predictions, the first step in sound maintenance management will be taken. A successive progress will be taken to prevent possible malfunctions when the modeled ANN in a future study can be revised to provide desired software continuity. Taking into account security, economy and system integrity; spare parts, time, personnel and organizational planning required for maintenance application will be provided by this methodology.

\section{References}

[1] Göksu, B. (2017). Gemi Dizel Makinelerinde Planlı Bakım Sistemi Uygulamaları ve Arıza Modlarının Analizi (MSc Thesis). Dokuz Eylül Üniversitesi.

[2] IMO. (2018). International Safety Management Code, IMO Publishing.

[3] Lazakis, I., Turan, O., \& Aksu, S. (2010). Increasing Ship Operational Reliability Through the Implementation of a Holistic Maintenance Management Strategy. Ships Offshore Struct. 5, 337357.

[4] Liu, L., Logan, K.P., Cartes D.A., \& Srivastava, S.K. (2007). Fault Detection, Diagnostics, and Prognostics: Software Agent Solutions. IEEE Trans. Veh. Technol. 56, 1613-1622.

[5] Coraddu, A., Oneto, L., Ghio, A., Savio, S., Anguita, D., \& Figari, M. (2016). Machine Learning Approaches for Improving Condition-Based Maintenance of Naval Propulsion Plants. Proc. Inst. Mech. Eng. Part M J. Eng. Marit. Environ. 230, 136-153.

[6] Macal, C., \& North, M. (2015). Introductory Tutorial: Agent-Based Modeling and Simulation. Proc. Winter Simul. Conf. 2015-January, 6-20.

[7] Sharma, A., Yadava, G.S., \& Deshmukh, S.G. (2011). A Literature Review and Future Perspectives on Maintenance Optimization. J. Qual. Maint. Eng. 17, 5-25.

[8] Swanson, L. (2001). Linking MaintenanceStrategiesto Performance. Int. J. Prod. Econ. 70, 237-244.

[9] Dekker, R. (1996). Applications of Maintenance Optimization Models: A Review and Analysis. Reliab. Eng. Syst. Saf. 51, 229-240.

[10] Spires, C. (1996). Asset and Maintenance Management - Becoming A Boardroom Issue. Manag. Serv. Qual. An Int. J. 6, 13-15. 
[11] Muchiri, P., Pintelon, L., Gelders, L., \& Martin, H. (2011). Development of Maintenance Function Performance Measurement Framework and Indicators. Int. J. Prod. Econ. 131, 295302.

[12] Moubray, J. (1999). Reliability-Centered Maintenance, 2nd ed. ButterworthHeinemann.

[13] Márquez, A.C. (2007). The Maintenance Management Framework: Models and Methods for Complex Systems Maintenance, Springer Science \& Business Media.

[14] Akyuz, E., \& Celik, M. (2017). Using of A'WOT to Design an Enhanced Planned Maintenance System (E-PMS) OnBoard Ship. Brodogradnja 68, 61-75.

[15] Hetherington, C., Flin, R., \& Mearns, K. (2006). Safety in Shipping: The Human Element. J. Safety Res. 37, 401-411.

[16] Turan, O., Olcer, A.I., Lazakis, I., Rigo, P., \& Caprace, J.D. (2009). Maintenance/ Repair and Production-Oriented Life Cycle Cost/Earning Model for Ship Structural Optimisation During Conceptual Design Stage. J. Econ. Behav. Organ. 4, 107-125.

[17] Lazakis, I., Turan, O., Alkaner, \& S., Olcer, A. (2009). Effective Ship Maintenance Strategy Using a Risk and Criticality Based Approach. 13 th Congr. Intl. Marit. Assoc. Mediterr. IMAM 12-15.

[18] Li, Y., Yao, Z., Huang, J., \& Xu, Y. (2011). Study on Comprehensive Evaluation Method of Ship Equipment Technical Condition. ICQR2MSE 2011 - Proc. 2011 Int. Conf. Qual. Reliab. Risk, Maintenance, Saf. Eng. 702-705.

[19] Hayman, B., Dogliani, M., Kvale, I., \& Magerholm Fet, A. (2000). Technologies for Reduced Environmental Impact from Ships - Ship Building, Maintenance and Dismantling Aspects. ENSUS 2000 Mar. Sci. Technol. Environ. Sustain. Dep. Mar. Technol. Sci. Coast. Manag. 1, 2-12.
[20] Anderson, P. (2015). The ISM Code: A Practical Guide to The Legal and Insurance Implications.Lloyd's Practical Shipping Guides, Informa Law from Routledge,2015.

[21] Isa, M. C., Yusoff, N. H. N., Nain, H., Yati, M. S. D., Muhammad, M. M., \& Nor, I. M. (2013). Ferrographic analysis of wear particles of various machinery systems of a commercial marine ship. Procedia Engineering, 68, 345-351.

[22] Dikis, K., Lazakis, I., \& Theotokatos, G. (2015). Dynamic reliability analysis tool for ship machinery maintenance.

[23] Gkerekos, C., Lazakis, I., \& Theotokatos, G. (2016). Ship machinery condition monitoring using vibration data through supervised learning.

[24] Emovon, I., Norman, R. A., \& Murphy, A. J. (2018). Hybrid MCDM based methodology for selecting the optimum maintenance strategy for ship machinery systems. Journal of intelligent manufacturing, 29(3), 519-531.

[25] Lazakis, I., Raptodimos, Y., \& Varelas, T. (2018). Predicting ship machinery system condition through analytical reliability tools and artificial neural networks. Ocean Engineering, 152, 404-415.

[26] Durán, O. (2011). Computer-Aided Maintenance Management Systems Selection Based on A Fuzzy AHP Approach. Adv. Eng. Softw. 42, 821829.

[27] O’Hanlon, T. (2004). Computerized Maintenance Management and Enterprise Asset Management Best Practices, Reliabilityweb.com Asset Management White Paper Series.

[28] Carnero, M.C., \& Novés, J.L. (2006). Selection of Computerised Maintenance Management System by Means of Multicriteria Methods. Prod. Plan. Control 17, 335-354. 
[29] Uysal, F., \& Tosun, Ö. (2012). Fuzzy TOPSIS-Based Computerized Maintenance Management System Selection. J. Manuf. Technol. Manag. 23, 212-228.

[30] Hagan, M.T., Demuth, H.B., Beale, \& M.H., Jesús, O. De. (2014). Neural Network Design, 2nd ed, Martin Hagan.

[31] Öztemel, E. (2012). Yapay Sinir Ağları, 3rd ed. Papatya Yayıncllı, Istanbul.

[32] Yüksek, A.G., Bircan, H., Zontul, M., \& Kaynar, O. (2007). Sivas İlinde Yapay Sinir Ağları ile Hava Kalitesi Modelinin Oluşturulması Üzerine Bir Uygulama. C.Ü. İktisadi ve İdari Bilim. Dergi. 8, 97-112.

[33] Basheer, I.A., \& Hajmeer, M. (2000). Artificial Neural Networks: Fundamentals, Computing, Design, and Application. J. Microbiol. Methods 43, 3-31.

[34] Suykens, J.A., Vandewalle, J.P., \& de Moor, B.L. (2012). Artificial Neural Networks for Modelling and Control Of Non-Linear Systems. Springer Science \& Business Media.

[35] Shanmuganathan, S., \& Samarasinghe, S. (2016). A Hybrid Artificial Neural Network (ANN) Approach to Spatial and Non-Spatial Attribute Data Mining: A Case Study Experience, Studies in Computational Intelligence. Springer International Publishing.

[36] Rafiq, M.Y., Bugmann, G.,\&Easterbrook, D.J. (2001). Neural Network Design for Engineering Applications. Comput. Struct. 79, 1541-1552. 